\title{
Office Management of Educational Institutions: Theories and Applications
}

\author{
Arif Prastiawan \\ Faculty of Education \\ Universitas Negeri Malang, Indonesia \\ arif.prastiawan@um.ac.id \\ Imam Gunawan \\ Department of Educational Administration \\ Universitas Negeri Malang, Indonesia \\ imam.gunawan.fip@um.ac.id
}

Arda Purnama Putra

Primary Education and Preschool

Universitas Negeri Malang, Indonesia

arda.purnama.fip@um.ac.id

\author{
Ence Surahman \\ Department of Educational Technology \\ Universitas Negeri Malang, Indonesia \\ ence.surahman.fip@um.ac.id \\ Dimas Arif Dewantoro \\ Department of Special Education \\ Universitas Negeri Malang \\ dimas.arif.fip@malang.ac.id \\ Puri Selfi Cholifah \\ Department of Primary School Education \\ Universitas Negeri Malang, Indonesia \\ puri.selfi.fip@um.ac.id
}

\author{
Ni Luh Sakinah Nuraini \\ Department of Primary School Education \\ Universitas Negeri Malang, Indonesia \\ niluh.sakinah.fip@um.ac.id
}

\begin{abstract}
All activities carried out by the organization require a place in supporting employee activities. The office is a place to support employees in carrying out their work in an organization. Therefore, efforts to carry out office activities need to be handled professionally, in the sense that the implementation of office activities requires leaders and staff who understand their duties, are enthusiastic in pursuing achievements, and an employee is expected to devote his attention seriously, and try to be able to cultivate information, so that it can be useful.
\end{abstract}

Keywords: office management, educational institutions

\section{INTRODUCTION}

The office comes from the Dutch language namely kantoor and in English namely the office. Office is where people work. Soerjani (1992) states the office is a place and activity or activities in supporting leaders to achieve goals. Office as a place is every room where paperwork is done. Office as a process is a series or activities that handle information, starting from receiving, concluding, processing, storing, and distributing. Whereas Sedarmayanti (2005) states that the office is the place where information handling processes start from receiving, collecting, processing, storing to distributing information.

The place to carry out this activity can be a building that has a variety of equipment to support the implementation of work properly. When referring to the narrow sense of the office, it can be understood that the office is a place for people to do organizational work that is bound by time and space at work. But along with the development of technology, the notion of office experiences an expansion of meaning that is not limited to the place and time of carrying out work, but the office is now incarnated in the form of an electronic office (eoffice). Besides that, once the office was associated as a place full of collisions with neat tables and chairs, now the office has been artistically designed.

Office management can be defined as planning, controlling, and organizing office work, and moving those who carry it out in order to achieve predetermined goals.
This has to do first with regard to the circulation of living data and information of the organization from its creation through the maintenance, distribution and storage if has a fixed value or annihilation if it is obsolete. The thing or target that is affected by the series of activities in general is the office work (office work). Soerjani (1992) states that office management is a series of activities for planning, organizing (organizing and organizing), directing (giving direction and direction), supervising, and controlling (controlling) to carry out in an orderly manner.

\section{OFFICE FUNCTIONS}

If referring to the description of the definition of the office, it can be understood that the function of the office is a place to work to complete organizational tasks. Office in practice is as a place to work for employees with a variety of documents that are managed. These documents, files or files are an inseparable part of the work and office functions. Office function is a concept that focuses on the use of the office as a place of work. The function of the office as a place of work is inseparable from the documents that are managed as material for organizational information.

Office functions include: (1) routine functions; (2) technical functions; (3) analysis function; (4) interpersonal function; and (5) managerial functions. Routine functions, which require thinking include archiving and copying. Technical functions, i.e. require adequate opinions, 
decisions and office skills. The function of analysis, which requires critical and creative thinking, is accompanied by the ability to make decisions. Interpersonal function, which requires assessment and analysis as a basis for decision making, as well as skills related to others. Managerial function, which requires planning, organizing, measuring, and motivating.

\section{PRINCIPLE OFFICE MANAGEMENT}

The principle of office is something that is the foundation of thought in the organization of offices in an organization. The principle of office management becomes the foundation in implementing an organization's office services. This principle is used as a reference for the operation of the office to suit the ideals of the organization, so as to satisfy the organization's customers. The principles that can be guided in the management of education office management are: there is a clear division of labour in each office section; there is no overlapping of work between the office sections; clarity of office service work circulation; record or record data of every office service; there is a clear division of tasks for each member; efficient use of organizational resources; checking of work; proportional flexibility; and services are carried out with a simple principle.

Denyer (2015) states that there are eleven principles that must be followed in implementing office management, namely: (1) the office system has a smooth work flow; (2) avoid the occurrence of work immunity or duplication of work (one job is done by several people); (3) maintain the pace of work; (4) must avoid unnecessary writing; (5) offices must make the best use of specialization in work (related to professionalization); (6) maintaining the use of paper efficiently; (7) applying management principles based on exceptions (principle of management by expectation); (8) working to make exceptions to the rules need to be minimized (on condition); (9) must avoid unnecessary checking; (10) make the best use of equipment, equipment or other elements in the sense of not over-using; and (11) using the principle of simplicity.

\section{OFFICE ENVIRONMENT AND PHYSICAL CONDITIONS}

For work to be done well, the work space needs to be arranged in such a way or using a good office layout. Office layout is an important factor that also determines the smooth work of employees, and the sense of satisfaction of employees and customers (guests). The better office layout will provide a sense of security and comfort in working and increase work productivity. So, an office requires a good arrangement of office space. Arrangement of office space starting from the placement of desks, chairs, office equipment must consider the area of the room and the number of employees in the room. Littlefield and Peterson stated that office spatial planning can be formulated as the preparation of furniture and equipment on the available floor area (Gie, 2007).

While Terry argues that office space layout is a determination of space requirements and about the detailed use of this space to prepare a practical arrangement of physical factors deemed necessary for the implementation of office work at a reasonable cost (Gie, 2007). The elements of the physical work environment according to
Anoraga and Widiyanti (2001) include aspects: (1) air exchange, namely so that each room is given adequate ventilation so that employees feel comfortable when working; (2) adequate lighting, for work that requires accuracy requires adequate lighting and not dazzling; and (3) noise, busy work environment can disturb concentration in carrying out work.

Meanwhile Tiffin and McCormick suggested several aspects of the physical work environment, namely: (1) work equipment, the available equipment is a component that supports work activities; (2) air circulation, adequate air circulation in the room is very necessary especially if in a room full of employees; (3) lighting, adequate indoor lighting facilities will support smooth work; (4) noise or noise, noise in the work environment will disturb concentration; and (5) work space layout, arrangement, colouring and cleanliness of each room will affect employees when doing work (Trianasari, 2005).

\section{OFFICE ORGANIZATION}

Office organization is a process by which people interact to achieve office goals. Office organization is a basic framework in which people carry out their activities to receive, store, process, and present information and maintain assets (assets). Haryadi (2009) suggested that office organizations include staffing and allocating tasks and responsibilities in processing data, supplying data, supplying information for decision making, and maintaining assets. Office organizations are built and driven on the foundation of organizational principles that contain truth.

The achievement of organizational goals according to Wursanto (2005) depends on the ability of the leadership in implementing organizational principles, namely: (1) the principle of clear objectives; (2) the principle of unitary command; (3) the principle of balance; (4) the principle of distribution of work; (5) the principle of oversight; (6) the principle of delegation of authority; (7) departmental and coordinating principles; (8) the principle of proper employee placement; and (9) satisfying reward principle.

Office organization is a tool that can facilitate the organization in providing services to its customers. Office organization will be clear when there is an office organizational structure and there is a clear division of each part of the office organization. Organizational structure is a picture that displays the flow of command and / or coordination of each part of the organization. Office organization with the existence of an organizational structure will make it easier for each member to work in accordance with their duties and responsibilities in a part of the organization. It is expected that with these conditions, organizational services can be carried out effectively and efficiently. The structure of the office organization structure must be adjusted to the size of the organization and / or at least the services provided by the office of the organization to customers.

\section{CORRESPONDENCE OFFICE}

Correspondence in office activities is defined as the technique of making letters and communicating with letters. Whereas the notion of a letter is a written communication tool originating from one party and addressed to another party with the aim of conveying 
information. Soetrisno and Renaldi (2006) state that if a letter from one party to another party contains information concerning the interests of the tasks and activities of the agency concerned, such a letter is called an official or official letter. Official letter is a letter used for the benefit of work, duties from the office, or official activities. This letter comes from an institution or institution both private and public. Example: letter of assignment, warrant, memorandum, and decision letter. Individual service letters are job application letters, permission requests, and leave requests.

Mail handling is often also referred to as mail handling, which is an activity of sending written information from one place to another. Letter handling activities in other words not only accept incoming letters and send outgoing letters. However, letter handling activities also include directing and distributing letters to work units within an organization or institution. Incoming letters are all official letters received by a government agency. To facilitate supervision and control, acceptance, management of incoming mails is centered in the administrative section or the leadership secretariat. Therefore, if an employee from any part receives an incoming letter from an outside agency, the first step that must be taken is to submit the entry letter to the administrative or secretariat department.

\section{ARCHIVES AND ARCHIVES}

Law Number 7 of 1971 concerning the Principal Provisions for Archiving Article 1 states: (1) texts prepared and accepted by state institutions and government bodies in any form, whether in a single or group condition in the context of carrying out government activities; and (2) texts made and accepted by private bodies and / or individuals in any form, whether single or group, in the context of implementing national life. Lundgren and Lundgren (1989) state that archives are evidence of an event or activity recorded in tangible or tangible form so that it is possible to be recovered.

Whereas Gie (2000) argues that an archive is a collection of slips which are stored systematically because they have a use so that whenever they are needed, they can be quickly recovered. Archives are very important role for providing organizational data on an ongoing basis. The archive functions in the future when needed. The following will be explained about: (1) type of archive; (2) the principle of archival storage; (3) archive storage system; (4) archive storage equipment; (5) electronic archive; (6) archive use value; (7) destruction of records; and (8) filing methods.

\section{Type of Archive}

Based on its function, the archive can be divided into two, namely: (1) dynamic archive; and (2) static archives. Dynamic archives are records that can be used directly in the process of planning and implementing an organization. Dynamic archives are classified into two, namely active and inactive records. Active archive is an archive that is used continuously at least 12 times a year. Inactive records are long-term records and are also called semi-active files. Whereas static archives are records that are not used in the functions of the creator's management organization, but can be used for educational and research purposes.

\section{Archive Storage Principle}

The principle of archival storage can be divided into three, namely: (1) the principle of centralization; (2) the principle of decentralization; and (3) combination principle. The principle of centralization is the principle of central or central archive storage. The advantages of an organization using the principle of centralized archive storage are: (1) preventing duplication; (2) better service; (3) uniformity; (4) save time; (5) save space, equipment and office stationery; and (6) archive security is guaranteed because it is easier to monitor.

While the disadvantages of organizations using the principle of archival storage with centralization are: (1) physical difficulties; (2) information leakage; (3) there is fear of loss of records; and (4) the user does not directly obtain the archive if an archive is needed.

The principle of decentralization is the principle of structuring or storing archives, both active and inactive records, with no focus on the parent of the administration but in their respective work units. The advantages of an organization using the principle of decentralized archive storage are: (1) close to users; (2) this principle is very suitable if confidential information relating to a part is stored in the relevant part; and (3) saving time and energy in transporting files.

While the disadvantages of organizations using the principle of archival storage with decentralization are: (1) supervision is relatively difficult; (2) there are many duplications of the same archive; (3) the proportion of work to store records is only one function of administrative staff; (4) experiencing filing difficulties relating to the relevant archives and relating to two or more parts; and (4) each section keeps its own archive so that the same archive is scattered in various places.

The principle of combination is that each part stores its own document or archive under the supervision of a centralized system. The advantages of an organization using the principle of archive storage in combination are: (1) the existence of a uniform storage system; (2) minimizing minimum filing errors and lost files; (3) suppressing file duplication; and (4) facilitates control of archive movements according to retention and annihilation schedules. While the disadvantages of organizations using the principle of archival storage in combination are: (1) making it difficult to use the archives in question because archived links are not placed in the same place; and (2) lack flexibility because uniformity in all units is not yet available.

\section{Archive Storage System}

An archive storage system or commonly referred to as a filing system is the activity of organizing and compiling archives in a systematic and logical order, storing and maintaining records for safe and economic use (Sedarmayanti, 2005).

The purpose of structuring files or files is: (1) so that records can be stored and recovered quickly and accurately; and (2) supporting the efficient and effective implementation of depreciation of records. Archive can be said as the process of copying files owned by an organization. This multiplication is intended as authentic proof of something related to the organization of the office. 


\section{Archive Storage Equipment}

Some things to consider in choosing archival storage equipment are: (1) the type of document to be stored; (2) space requirements; (3) security considerations; (4) required utilization speed; (5) equipment costs; (6) storage operational costs; and (7) the number of users who access documents on a regular basis. Therefore, archival storage equipment must be really durable, for example resistant to temperature, humidity, heat, or fire. Archive storage equipment should be adjusted to the interests of the archive storage itself.

\section{Electronic Records}

The National Archives and Record Administration (2015) states that electronic records are records that are stored and processed in a formal setting, where only computers can process them, so they are often said to be machine-readable records. The benefits of electronic archive management according to Sukoco (2007) are: (1) quickly found and allows the use of archives or documents without leaving the desk; (2) indexing that is flexible and easily modified based on procedures that have been developed will save energy, time, and costs; (3) full-text search; (4) it is unlikely that the file will be lost; (5) save space; (6) digitally archiving; (7) easy file sharing; (8) increase security; and (9) data recovery is easy.

While the weaknesses of electronic archive management are: (1) there are opportunities to manipulate files; (2) difficulties in sharing files due to file formats and network availability or access to share files with others; and (3) the possibility of file corruption at any time without prior indication. If you pay attention to the weaknesses of the electronic archive system, then it is necessary for an organization to have more than one hard disk data, each specified period of archived files stored on a backup hard disk. This means that organizations do not only have one data storage, but more than one storage hard disk.

\section{Archive Value}

The use value of records is the value of records that are based on the usefulness of an office. This use value is the basis for determining the retention schedule for each file or document based on the serial number. Basuki (2003) states the use value of the archive in terms of the interests of the office, are: (1) primary use value; and (2) secondary use values.

Primary use values include: (1) administrative use values, in the form of use values of documents used in determining the policy of an office; (2) fiscal use value, in the form of use value of documents relating to the use of office finance for audit and operational purposes; (3) legal use value, in the form of document use value for offices concerning legal interests; and (4) historical use value, in the form of document value stored for historical purposes that records an event in an activity.

Secondary use values include: (1) proof of use value, of how a school is established, developed, managed, and the implementation of its functions and activities; and (2) informational use value, involving information for research and historical purposes without being affirmed by the organization of creation. Office management in schools, has a strategic role to bridge between the school customers (students, the community, and stakeholders) with the school itself.

\section{Destruction of Archives}

Destruction of records is the activity of destroying and eliminating physical and archival information through certain means, so that the physical and information are no longer recognized. Archive destruction can also be done because the function of archived documents no longer matters. Therefore, the office can destroy the archive by using the minutes of the destruction of the archive. The procedure for destroying records is: (1) selection of files to be destroyed; (2) making a list of the types of records to be destroyed (list of information); (3) making minutes of destruction or deletion of records; and (4) the extermination involved witnesses.

\section{Archiving Methods}

There are four archiving methods, namely: (1) alphabetical system; (2) the subject filling system (subject); (3) number filling system; and (4) regional or geographical filling systems. The alphabetical system is the basis of other systems. Archives are classified based on the name of the person, agency name, company name or item name, form, and so on. The arrangement of the archives in alphabetical order follows the Latin letters A to Z. The use of the caption capture word makes it easy to find the archive again. A catch word is a name or number that is used to identify an archive for the purpose of filling. Caption in the alphabetical system is the name of a person or organization. For example: Achmad, Chairudin, Darmanto, the State Administration Institute, and PT Pusri.

The subject filling system (subject) applies a rare step: (1) determines in advance what problems are generally disputed in daily letters; and (2) grouping problems into one subject. For example: Staffing includes leave, promotions, and applications; and Finance includes salaries, Eid gifts and overtime. The number filling system is in principle almost the same as the alphabetical system, where the name of a person or institution is replaced by a number code. Number filling systems Widely used in hospitals, insurance companies, and banks.

Three ways to store files with a number filling system are: (1) consecutive numbers; (2) middle number (middle digit); and (3) final number (terminal digit). The three elements in the number system are: (1) the main file (ledger), using two folders, namely: (a) mixed folders, each incoming or outgoing letter to and from a correspondent that is not more than five will be mixed into one with the letters originating from other correspondents; and (b) an individual folder, incoming or outgoing mail of one correspondent whose number has reached five letters will be moved into the individual folder and stored in the main file; (2) index, which is a tool to find out the file number that has been given to a correspondent (name), made in the form of a card from manila carton with a length of $12.5 \mathrm{~cm}$ and a width of $7.5 \mathrm{~cm}$; and (3) number books, i.e. books that contain numbers that have been used as correspondent numbers (names) in file numbers, archives are numbered starting from small numbers and continue to increase or according to the tenths system, for example 00, 10, 20, 30, and so on. 
The storage arrangement with the number filling system is: (1) sequential numbers, i.e. archives are numbered starting from small numbers and continue to increase or according to the tenths system, for example 00 , $10,20,30$, and so on; (2) the middle number, only two numbers are used, for example the archive number 123456 , then the file is stored under instruction number 34; and (3) final number.

Regional (geographical) filling system is an archive storage system according to region distribution. For example: Banten includes Cilegon, Serang, Pandeglang, Tangerang and so on; West Java includes Bandung, Ciamis, Cirebon, Sukabumi, and others; East Java includes Surabaya, Kediri, Malang, and others.

\section{CONCLUSION}

Activities carried out on the substance of education management in schools, basically empirically carried out by school office management. For example, in the management of students, there is scope for activities to make student handbooks, in schools the part that makes student handbooks is the office. So that the management of educational offices in schools is a supporting factor of the substance of education management activities in schools. But the thing that needs to be understood is that education office management is not the substance of education management. Modern offices are offices that embrace philosophy, nature, attitudes, and ways of thinking, and act in accordance with the times.

\section{REFERENCES}

[1] Anoraga, P., \& Widiyanti, N. 2001. Psikologi dalam Perusahaan. Jakarta: Rineka Cipta.
[2] Basuki, S. 2003. Manajemen Arsip Dinamis: Pengantar Memahami dan Mengelola Informasi dan Dokumen. Jakarta: Gramedia.

[3] Denyer, J. C. 2015. Office Management. New York: Pearson.

[4] Gie, T. L. 2007. Administrasi Perkantoran Modern. Yogyakarta: Liberty.

[5] Haryadi, H. 2009. Administrasi Perkantoran untuk Manajemen \& Staf. Jakarta: Transmedia.

[6] Law Number 7 of 1971 concerning the Principal Provisions for Archiving. Jakarta: Fokus Media.

[7] Lundgren, T. D., \& Lundgren, C. A. 1989. Records Managements in The Computer Age. Boston: Kent Publishing.

[8] The National Archives and Record Administration. 2015. Charters of Freedom Bundle. Retrieved 25 July 2019, from https://www.nationalarchivesstore.org/products/chartersof-freedom-bundle.

[9] Sedarmayanti. 2005. Manajemen Sumber Daya Manusia. Bandung: Refika Aditama.

[10] Soerjani. 1992. Pengelolaan Kantor Pendidikan. Malang: POPF-IKIP Malang.

[11] Soetrisno, \& Renaldi, B. 2006. Manajemen Perkantoran: Modul Pendidikan dan Pelatihan Prajabatan Golongan I dan II. Retrieved 25 July 2019, from http://diklat.jogjaprov.go.id/v2/downloadmateri/category/7-diklat-prajabatan-golongan-iii?download=50: manajemen-perkantoran-modern.

[12] Sukoco, B. M. 2007. Manajemen Administrasi Perkantoran Modern. Jakarta: Erlangga.

[13] Trianasari, Y. 2005. Hubungan antara Persepsi terhadap Insentif dan Lingkungan Kerja dengan Loyalitas Kerja. Thesis. Surakarta: Fakultas Psikologi Universitas Muhammadiyah Surakarta.

[14] Wursanto. 2005. Dasar-dasar Ilmu Organisasi. Yogyakarta: Andi. 